\title{
Certain Imidazotetrazines Escape 06-Methylguanine-DNA Methyltransferase and Mismatch Repair
}

\author{
Jihong Zhang ${ }^{d}$ Malcolm F.G. Stevens ${ }^{a}$ Marc Hummersone ${ }^{c}$ \\ Srinivasan Madhusudan ${ }^{b}$ Charles A. Laughton ${ }^{a}$ Tracey D. Bradshaw ${ }^{a}$ \\ ${ }^{a}$ Centre for Biomolecular Sciences, University of Nottingham, b Academic Unit of Clinical Oncology, City Hospital, \\ and ${ }^{C}$ Pharminox Ltd, BioCity, Nottingham, UK; ${ }^{d}$ Faculty of Life Science and Technology, Kunming University of \\ Science and Technology, Yunnan, China
}

\section{Key Words}

Glioblastoma multiforme · Temozolomide •

O6-methylguanine-DNA methyltransferase •

Imidazotetrazines $\cdot$ Anticancer activity

\begin{abstract}
Resistance to temozolomide (TMZ), conferred by O6-methylguanine-DNA methyltransferase (MGMT) or mismatch repair (MMR) deficiency, presents obstacles to successful glioblastoma multiforme (GBM) treatment. Activities of novel $\mathrm{TMZ}$ analogs, designed to overcome resistance, were tested against isogenic SNB19 and U373 GBM cell lines ( $V=$ vector control, low MGMT; M = MGMT overexpression). TMZ and triazene MTIC demonstrated >9-fold resistance in SNB19M cells (cf SNB19V). N-3 methyl ester analog 11 and corresponding triazene 12 inhibited growth of TMZ-sensitive $(\mathrm{V})$ and TMZ-resistant $(\mathrm{M})$ cells $\left(\mathrm{Gl}_{50}<50 \mu \mathrm{M}\right)$. Ethyl ester 13 and triazene 14 gave similar profiles. MMR-deficient colorectal carcinoma cells, resistant to $\mathrm{TMZ}\left(\mathrm{Gl}_{50}>500 \mu \mathrm{M}\right)$, responded to analog 11 and 13 treatment. Cross-resistance to these agents was not observed in cell lines possessing acquired TMZ resistance (SNB19VR; U373VR). Methyl ester 11 blocked SNB19V, SNB19M and SNB19VR cells in $S$ and $G_{2} / M$, causing dose- and time-dependent apoptosis. DNA damage, recruiting excision repair was detected by alkaline comet assay; $\mathrm{H} 2 \mathrm{AX}$
\end{abstract}

phosphorylation indicated a lethal DNA double-strand break formation following analog 11 exposure. Compounds 11 and 13 demonstrated 3.7- and 5.1-fold enhanced activity in base excision repair-deficient Chinese hamster ovary cells; furthermore, poly (ADP-ribose) polymerase-1 inhibition potentiated HCT-116 cells' sensitivity to analog 11 . In conclusion, analogs 11 and 13 exert anticancer activity irrespective of MGMT and MMR.

Copyright $\odot 2011$ S. Karger AG, Basel

\section{Introduction}

Glioblastoma multiforme (GBM; grade IV astrocyto$\mathrm{ma}$ ) is the most prevalent and lethal primary malignant adult brain tumor $[1,2]$. Standard of care therapy comprises surgery, radiotherapy and adjuvant alkylating agent temozolomide (TMZ) conferring a median survival time of 14.6 months compared with 12.1 months for GBM patients treated with radiotherapy alone [3]. Patients whose tumors possess transcriptional silencing of O6-methylguanine-DNA methyltransferase (MGMT), mediated by gene promoter methylation, gain greatest survival benefit from treatment with TMZ (median survival 21.7 vs. 15.3 months) $[3,4]$. TMZ, an orally available imidazotetrazine monofunctional DNA-alkylating agent, is rapidly ab-

\section{KARGER}

Fax +4161306 1234 E-Mail karger@karger.ch www.karger.com

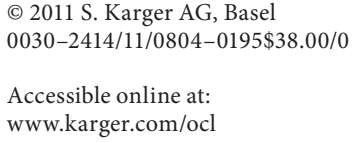

Dr. Tracey Bradshaw

Centre for Biomolecular Sciences

University of Nottingham

Nottingham, NG7 2RD (UK)

E-Mail tracey.bradshaw@nottingham.ac.uk 
sorbed to undergo spontaneous breakdown, forming monomethyltriazene 5-(3-methyltriazen-1-yl)-imidazole-4-carboxamide (MTIC) under physiological conditions. MTIC further reacts with water to liberate 5-aminoimidazole-4-carboxamide (AIC) and the highly reactive methyldiazonium cation. The methyldiazonium cation methylates DNA purine residues, preferentially $\mathrm{O} 6$ guanine (O6-MeG, 6\%) in guanine-rich regions $[5,6]$, but also N-7 guanine (N7-MeG, 70\%) and N-3 adenine (N3MeA, 9\%) [6]. TMZ cytotoxicity is mediated mainly through the mutagenic, carcinogenic and cytotoxic O6$\mathrm{MeG}$ lesion [7]. During DNA replication, unrepaired O6$\mathrm{MeG}$ mispairs with thymine, triggering DNA mismatch repair (MMR) [8]. MMR exclusively recognizes and removes mismatched thymine, only to reinsert thymine opposite unrepaired O6-MeG. Therefore, futile cycles of thymine excision and reinsertion lead to persistent DNA strand breaks triggering cell cycle arrest and apoptosis [9].

The suicidal DNA repair protein MGMT stoichiometrically and rapidly removes alkyl groups such as methyl, ethyl, chloroethyl, n-propyl, etc. from O6-modified guanine [10]; its expression in gliomas is associated with resistance to alkylating agents [11].

Quantitatively more numerous N7-MeG and N3-MeA lesions are subject to rapid base excision repair (BER) [12] facilitated by poly(ADP-ribose) polymerase-1 (PARP-1) [13]. N7-MeG does not appear to be a markedly cytotoxic lesion, whereas N3-MeA is highly lethal if not repaired. TMZ cytotoxicity is therefore mainly dependent on O6MeG lesions which alert MMR, subsequently leading to outcomes such as G2/M cell cycle arrest, cellular senescence, late apoptosis $(>120 \mathrm{~h})$, and autophagy in glioma cells [14-16].

Gliomas, like most tumors, possess inherent or develop acquired drug resistance, thwarting effective therapy [17]. As the mechanism of cytotoxicity of TMZ is dependent on intact MMR and inversely related to MGMT activity [18], intrinsic resistance of tumor cells is mainly dependent on either high MGMT levels or MMR deficiency. MGMT activity varies widely in different tumor types and cell lines. Mutations in DNA MMR genes cause hereditary nonpolyposis colorectal cancer (HNPCC) and are associated with a significant proportion of sporadic cancers [19]. Given the negative clinical impact of acquired resistance, GBM cell lines were generated possessing acquired resistance to TMZ [20]. Molecular mechanisms of resistance to TMZ in vitro were identified, MMR loss and MGMT upregulation, consistent with acquired resistance, emerging clinically during TMZ treatment and tumor progression [21-23]. In this paper, we advance the possibility that imidazotetrazines structurally related to TMZ but with different N-3 monofunctional alkylation potential might generate cytotoxic lesions in DNA which would not be repaired by MGMT and would be unaffected by MMR status.

The favorable physicochemical and pharmacokinetic properties of TMZ are conducive to oral administration, efficient penetration of the blood-brain barrier and convenient use in an outpatient setting [24]. In this program, novel TMZ analogs have been synthesized, maintaining the core imidazotetrazine structure [25] with the ultimate objective of developing a new agent suitable for GBM tumors which express high MGMT levels: moreover, such an agent might have broad-spectrum application against common tumors which do not respond to TMZ. Analog activity has been examined in isogenic GBM (MGMT/vector control transfection) and MMRdeficient colorectal carcinoma (CRC) cell lines. Perturbations in cell cycle progression caused by TMZ and novel imidazotetrazines in the presence and absence of DNA damage checkpoint inhibitor UCN01 have been compared. The role of DNA damage invoking BER has been explored with the aid of a PARP inhibitor and also in $\mathrm{BER}+/$ - isogenic cells. The kinetics of DNA single-strand excision and repair have been investigated by alkaline comet assay, and the conversion of lesions to more lethal DNA double-strand breaks ( $\gamma \mathrm{H} 2 \mathrm{AX}$ foci formation) examined. In this pilot study, we demonstrate that certain compounds inhibit glioma and CRC cell growth in vitro, irrespective of MGMT and MMR status [26]. DNA damage recruiting BER precedes cell death.

\section{Materials and Methods}

\section{Reagents}

TMZ was provided by Schering-Plough Research Institute (Kenilworth, N.J., USA). New analogs [25] (synthesized at Pharminox Ltd, BioCity, Nottingham, UK) were prepared as $100 \mathrm{mM}$ stock solutions in dimethyl sulfoxide (DMSO) and stored at $-20^{\circ} \mathrm{C}$. Reagents, unless specified otherwise, originated from Sigma-Aldrich Ltd (Poole, UK). Comet assay kits were purchased from Invitrogen (UK).

Cell Lines and Culture Conditions

SNB19V, U373V (vector) and isogenic MGMT-transfected human GBM cell lines SNB19M and U373M, respectively, were provided by Schering-Plough; SNB19VR, MMR-deficient (hMSH6-) SNB19V and U373VR, MGMT-upregulated U373V variants, were generated by selection for resistance to TMZ [20]. GBM cells were maintained in RPMI 1640 plus 10\% fetal bovine serum (FBS), $1 \%$ nonessential amino acids, $50 \mu \mathrm{g} / \mathrm{ml}$ gentamicin and $400 \mu \mathrm{g} / \mathrm{ml}$ G418. HCT-116 (hMLH1-deficient) and DLD-1 (hMSH6 mutant) 
CRC cells, obtained from the American Type Culture Collection, were grown in RPMI media supplemented with 10\% FBS. EM9V (XRCC1-deficient) and EM9XH (XRCC1-transfected) Chinese hamster ovary $(\mathrm{CHO})$ cells were gifts from Professor K.W. Caldecott $[27,28]$ (Centre for Genome Damage and Stability, University of Sussex, UK) and maintained in DMEM plus 10\% FBS and $1 \mathrm{mg} / \mathrm{ml} \mathrm{G} 418$.

\section{Growth Inhibitory Assays}

Cells were seeded into 96 -well plates $\left(6.5 \times 10^{2} /\right.$ well $)$. Following overnight incubation, the vehicle control, TMZ and analogs were added to the wells $(n=4-8$; final concentrations $0.5-1,000$ $\mu \mathrm{M})$. For combination studies, TMZ was added to the wells with or without NU1025 (100 $\mu \mathrm{M})$. MTT assays were performed at the time of agent addition and then following 7 days of incubation $\left(37^{\circ} \mathrm{C}, 5 \% \mathrm{CO}_{2}\right)$.

MTT [3-(4,5-dimethylthiazol-2-yl)-2,5-diphenyltetrazolium bromide] was added to the wells $(50 \mu \mathrm{l} ; 0.4 \mathrm{mg} / \mathrm{ml})$. The plates were reincubated $(4 \mathrm{~h})$ allowing MTT metabolism by viable cells to formazan crystals. Medium and unconverted MTT were aspirated and DMSO $(150 \mu \mathrm{l})$ was added to each well. Ensuring formazan solubilization, absorbance was read on an Anthos Labtec Systems plate reader $(550 \mathrm{~nm})$ and data transferred to a computer using Deltasoft $3^{\mathrm{TM}}$ software. Agent concentrations causing $50 \%$ growth inhibition $\left(\mathrm{GI}_{50}\right)$ were calculated.

Clonogenic assays measuring tumor cell survival and subsequent proliferative ability following agent exposure were performed. Exponentially growing EMV9 or EM9XH cells were seeded in triplicate (200 cells/well; 6-well plates) and allowed to attach overnight. Attached single cells were exposed to concentrations of TMZ and compounds 11 and 13 for $18 \mathrm{~h}$. Cells were washed and incubated for 9 days in fresh medium. Colonies, stained with $0.5 \%$ methylene blue, were counted.

\section{Cell Cycle Analysis}

Cell cycle perturbations were analyzed by flow cytometry following propidium iodide (PI) staining of DNA [29]. Exponentially growing cells were harvested and seeded in 6-well plates $\left(5 \times 10^{4}\right.$ cells/well; $2 \mathrm{ml}$ medium). Cells were incubated overnight, then treated with agent or vehicle. Following incubation $(24,48,72,120 \mathrm{~h})$, attached and floating cells were pooled and pelleted by centrifugation $\left(1,200 \mathrm{rpm}\right.$, at $\left.4^{\circ} \mathrm{C}, 5 \mathrm{~min}\right)$. Pellets were washed (PBS), cells resuspended in $0.3 \mathrm{ml}$ hypotonic fluorochrome solution $(0.1 \%$ sodium citrate, $0.1 \%$ Triton X-100, $50 \mu \mathrm{g} /$ $\mathrm{ml} \mathrm{PI}$ and $0.1 \mathrm{mg} / \mathrm{ml}$ ribonuclease A) and stored overnight at $4^{\circ} \mathrm{C}$ in the dark. Fluorescence of PI-stained DNA was detected on a Beckman Coulter EPICS-XL MCL ${ }^{\mathrm{TM}}$ flow cytometer and data were analyzed using EXPO32 ${ }^{\mathrm{TM}}$ software.

\section{Western Blot Analysis}

Cellular proteins $(50 \mu \mathrm{g})$ were separated by $12 \%$ SDS polyacrylamide gel electrophoresis and blotted onto PVDF membranes. Membranes were blocked ( $2 \mathrm{~h}$; at room temperature; $5 \%$ BSA in TBST), incubated with primary antibody (overnight; at $4{ }^{\circ} \mathrm{C} ; 0.75 \mu \mathrm{g} / \mathrm{ml}$, anti- $\gamma \mathrm{H} 2 \mathrm{AX}$, clone JBW301), washed $(3 \times$ TBST), and incubated with horseradish-peroxidase-coupled secondary antibody 1:10,000 (Pierce, UK; 2 h). After 3 final washes, blots were developed using chemiluminescence detection (Supersignal West Pico Chemiluminescent substrate kit; Pierce).

Imidazotetrazines Escape MGMT and MMR

\section{Alkaline Comet Assay}

Comet assays were performed under alkaline conditions according to the supplier's protocol (R\&D Systems). Exponentially growing cells were harvested, seeded in 6 -well plates $\left(1 \times 10^{5}\right.$ cells/well; $2 \mathrm{ml}$ culture medium) and allowed to attach overnight. Control samples were collected before treatment. Following $2 \mathrm{~h}$ exposure to the agent, cells were washed (PBS) and samples collected immediately (T0); agent-free medium was added to all other plates. Samples were collected at $0.5,1,2,3,4$ and $5 \mathrm{~h}$ thereafter. Cells were trypsinized, centrifuged $\left(1,200 \mathrm{rpm} ; 5 \mathrm{~min}\right.$ at $\left.4^{\circ} \mathrm{C}\right)$ and pellets suspended in freezing medium (95\% FBS and 5\% DMSO). Cell suspension $(20 \mu \mathrm{l})$ was mixed with $180 \mu \mathrm{l}$ of molten $1 \%$ lowmelting-point agarose in $\mathrm{PBS}$ at $37^{\circ} \mathrm{C}$, and $75 \mu \mathrm{l}$ was transferred onto slides. These slides were placed in the dark (at $4^{\circ} \mathrm{C} ; 10 \mathrm{~min}$ ). After agarose solidification, the slides were immersed in prechilled lysis solution (2.5 M NaCl, 100 mM EDTA, pH 10, $10 \mathrm{~mm}$ Tris base, $1 \%$ sodium laurylsarcosinate and $1 \%$ Triton X-100) protected from light (at $4{ }^{\circ} \mathrm{C} ; 1 \mathrm{~h}$ ), washed and incubated in fresh alkaline electrophoresis solution (1 mM EDTA, $300 \mathrm{~mm} \mathrm{NaOH}$; $\mathrm{pH}>13$; $1 \mathrm{~h}$ ). Electrophoresis was conducted for $30 \mathrm{~min}$ at $20 \mathrm{~V}$ $(1 \mathrm{~V} / \mathrm{cm}$, current $300 \mathrm{~mA})$ in alkaline electrophoresis solution. Comet slides were stained with diluted SYBR Green and examined by fluorescence microscopy (Olympus) equipped with an excitation filter $(510-550 \mathrm{~nm})$ with a $20 \times$ objective. Analyses were performed using the Comet Assay III scoring system (Perceptive Instruments, Haverhill, UK). Fifty cells were analyzed per slide with 2 slides per treatment. Tail moment (comet tail length $\times \%$ tail DNA $\times 0.01)$ was used to quantify data.

\section{Results}

\section{Activity of Imidazotetrazines against Human Glioma Cell Lines}

Cells possessing low/negligible MGMT activity (SNB19V, U373V) were sensitive to the growth-inhibitory properties of TMZ, yielding $\mathrm{GI}_{50}$ values of 35.7 and 68.0 $\mu \mathrm{M}$, respectively (table 1 ). In contrast, SNB19M and U373M cell lines, transfected with MGMT, demonstrated 13.2- and 5.4-fold inherent resistance to TMZ $\left(\mathrm{GI}_{50}\right.$ values: 469.9 and $368.7 \mu \mathrm{M}$, respectively). Compounds generally equiactive or more potent than TMZ in TMZ-sensitive SNB19V cells and also active in TMZ-resistant SNB19M cells were deemed 'worthy of further evaluation', whereas compounds exhibiting mean $\mathrm{GI}_{50}$ values above that of TMZ in SNB19V cells were not pursued further. Analogs with a lipophilic R group, such as cycloalkyl substituents (3-6) at the N-3 position, were much less active against SNB19V/M and U373V/M cell lines, with cyclobutyl (1)-, cyclopentyl (3)- and cyclohexyl (4)-substituted analogs exhibiting $\mathrm{GI}_{50}$ values $>150 \mu \mathrm{M}$. Poor activity was presumably a consequence of the substituents' greater steric bulk and hydrophobicity. Trimethylsilylmethyl derivative (7) revealed similar activity to that of 
Table 1. Activity of imidazotetrazines against human glioma cell lines

\begin{tabular}{|c|c|c|c|c|c|c|}
\hline \multirow[t]{2}{*}{ Compound } & \multirow[t]{2}{*}{ Series } & \multirow[t]{2}{*}{$\mathrm{R}$} & \multirow[t]{2}{*}{ SNB19V } & \multicolumn{3}{|c|}{ Cell lines $\mathrm{GI}_{50}, \mu \mathrm{M}^{\mathrm{b}}$} \\
\hline & & & & SNB19M & U373V & U373M \\
\hline TMZ & $\mathrm{A}$ & $\mathrm{Me}$ & $36 \pm 12$ & $470 \pm 89$ & $68 \pm 32$ & $369 \pm 86$ \\
\hline MTIC & B & $\mathrm{Me}$ & $51 \pm 18$ & $472 \pm 89$ & $94 \pm 40$ & $398 \pm 34$ \\
\hline MTZ & $\mathrm{A}$ & $\mathrm{CH}_{2} \mathrm{CH}_{2} \mathrm{Cl}$ & $13 \pm 7$ & $68 \pm 4$ & $22 \pm 13$ & $40 \pm 5$ \\
\hline 1 & A & cyclobutyl & $428 \pm 77$ & $550 \pm 116$ & $306 \pm 73$ & $360 \pm 13$ \\
\hline 2 & $\mathrm{~B}$ & cyclobutyl & $975 \pm 36$ & $904 \pm 25$ & $625 \pm 28$ & $599 \pm 41$ \\
\hline 3 & A & cyclopentyl & $292 \pm 36$ & $265 \pm 38$ & $166 \pm 4$ & $216 \pm 17$ \\
\hline 4 & A & cyclohexyl & $>1,000$ & $>1,000$ & $>1,000$ & $>1,000$ \\
\hline 5 & A & $\mathrm{CH}_{2} \mathrm{Ph}$ & $140 \pm 80$ & $180 \pm 86$ & $165 \pm 108$ & $178 \pm 134$ \\
\hline 6 & A & $\mathrm{CH}_{2} \mathrm{CH}_{2} \mathrm{Ph}$ & $99 \pm 26$ & $86 \pm 14$ & $115 \pm 91$ & $91 \pm 38$ \\
\hline 7 & A & $\mathrm{CH}_{2} \mathrm{Si}(\mathrm{Me})_{3}$ & $28 \pm 6$ & $302 \pm 69$ & $46 \pm 14$ & $250 \pm 72$ \\
\hline 8 & A & $\mathrm{CH}_{2} \mathrm{CF}_{3}$ & $40 \pm 6$ & $52 \pm 11$ & $102 \pm 33$ & $95 \pm 24$ \\
\hline 9 & A & $\mathrm{CH}_{2} \mathrm{Cl}$ & $35 \pm 14$ & $31 \pm 8$ & $29 \pm 8$ & $24 \pm 1$ \\
\hline 10 & A & $\mathrm{CH}_{2} \mathrm{OMe}$ & $31 \pm 9$ & $33 \pm 9$ & $26 \pm 5$ & $33 \pm 9$ \\
\hline 11 & A & $\mathrm{CH}_{2} \mathrm{CO}_{2} \mathrm{Me}$ & $47 \pm 17$ & $49 \pm 15$ & $32 \pm 22$ & $46 \pm 17$ \\
\hline 12 & $\mathrm{~B}$ & $\mathrm{CH}_{2} \mathrm{CO}_{2} \mathrm{Me}$ & $48 \pm 6$ & $50 \pm 7$ & $33 \pm 20$ & $46 \pm 10$ \\
\hline 13 & A & $\mathrm{CH}_{2} \mathrm{CO}_{2} \mathrm{Et}$ & $52 \pm 4$ & $61 \pm 5$ & $63 \pm 11$ & $56 \pm 6$ \\
\hline 14 & $\mathrm{~B}$ & $\mathrm{CH}_{2} \mathrm{CO}_{2} \mathrm{Et}$ & $34 \pm 3$ & $37 \pm 12$ & $30 \pm 20$ & $23 \pm 12$ \\
\hline 15 & A & $\mathrm{CH}_{2} \mathrm{CO}_{2} \mathrm{H}$ & $265 \pm 13$ & $296 \pm 17$ & $70 \pm 43$ & $140 \pm 106$ \\
\hline
\end{tabular}

a Glioma cell lines SNB19V and U373V (vector only, MGMT activity 4 and $56 \mathrm{fmol} / \mathrm{mg}$, respectively); SNB19M and U373M (stable MGMT transfection, MGMT activity 649 and $648 \mathrm{fmol} / \mathrm{mg}$, respectively).

${ }^{\mathrm{b}} \mathrm{GI}_{50}$ values of compounds were determined by 7-day MTT assay and are shown as the mean \pm SD of 2 or 3 independent experiments ( $\mathrm{n}=4$ per experiment). All compounds were dissolved in DMSO at stock concentration $100 \mathrm{mM}$ (stored at $-20^{\circ} \mathrm{C}$ ) and diluted in culture medium immediately prior to use.

TMZ against SNB19V/M and U373V/M cell lines. In contrast, replacement of the methyl group with small groups bearing extra halogen or oxygen atoms (8-14) resulted in compounds with activity against SNB19V/M cell lines. Trifluoroethyl (8), chloromethyl (9), methoxymethyl (MOM; 10) methyl ester (11) and ethyl ester (13) N-3-substituted analogs elicited a desirable potency against glioma cell lines, irrespective of MGMT. This activity may be a consequence of DNA alkylation lesions possessing poor hydrophobic interactions, insufficient to drive molecular recognition within the active binding pocket of MGMT.

Prodrug TMZ transports methyldiazonium ions to guanine-rich bases within the major groove of DNA [30]. MTIC, generated upon the TMZ ring opening, displays similar inhibitory properties to TMZ in glioma cell lines (table 1) consistent with the mechanism of chemical decomposition of TMZ to MTIC; MTIC further reacts with water to generate active methyldiazonium which alkylates DNA [30]. To confirm that novel analogs possess similar mechanisms of ring opening to TMZ, triazene compounds were synthesized and $\mathrm{GI}_{50}$ values compared with those of the corresponding imidazotetrazines (table 1).
Cyclopropylmethyltriazene 2 inactivity paralleled the inactivity of corresponding cyclopropylmethylimidazotetrazinone (1). Methyl/ethyl-substituted triazenes $(12,14)$ retained the potency of methyl/ethyl-substituted imidazotetrazinone counterparts $(11,13)$. These results indicate that novel methyl/ethyl ester imidazotetrazinones act as chemically activated prodrugs of monoalkyltriazenes.

\section{Activity of Imidazotetrazines against CRC and TMZ Acquired Resistant Glioma Cell Lines}

The growth-inhibitory activity of TMZ analogs was determined in $h M L H$ mutant HCT-116 and $h M S H 6$ mutant DLD-1 MMR-deficient CRC cells. HCT-116 and DLD-1 cells demonstrated inherent resistance to TMZ $\left(\mathrm{GI}_{50}\right.$ values 579.9 and $501.4 \mu \mathrm{M}$, respectively). Interestingly, MOM (10), methyl ester (11) and ethyl ester (13) analogs revealed potency against HCT-116 and DLD-1 cells $\left(\mathrm{GI}_{50}\right.$ values $<70 \mu \mathrm{M}$; table 2$)$.

To investigate whether analogs were able to circumvent acquired TMZ resistance, glioma cell lines demonstrating acquired resistance to TMZ were generated and molecular mechanisms conferring resistance were de- 
Table 2. Activity of imidazotetrazines against colon- and TMZ-acquired resistant glioma cell lines

\begin{tabular}{lcccc}
\hline Compound & \multicolumn{4}{l}{ Cell line $\mathrm{GI}_{50}, \mu \mathrm{M}^{\mathrm{a}}$} \\
& HCT-116 & DLD & SNB19VR & U373VR \\
\hline TMZ & $590.6 \pm 15.5$ & $501.4 \pm 93.5$ & $280.2 \pm 18.8$ & $288.8 \pm 33.2$ \\
MOM (10) & $53.3 \pm 4.5$ & $43.4 \pm 19.0$ & $25.7 \pm 5.2$ & $32.6 \pm 14.5$ \\
Methyl ester (11) & $44.6 \pm 19.1$ & $49.6 \pm 30.1$ & $52.3 \pm 9.4$ & $61.9 \pm 10.5$ \\
Ethyl ester (13) & $65.6 \pm 0.6$ & $67.9 \pm 9.6$ & $49.8 \pm 17.3$ & $64.3 \pm 9.6$ \\
\hline
\end{tabular}

HCT-116 = MMR-deficient hMLH1 mutant; DLD = MMR-deficient hMSH6 mutant; SNB19VR = TMZacquired resistant cell line derived from SNB19V, loss of expression of hMSH6; U373VR = TMZ-acquired resistant cell line derived from U373V, upregulation of MGMT.

${ }^{\text {a }} \mathrm{GI}_{50}$ values of compounds were determined by 7-day MTT assay and are shown as the mean \pm SD of 2 or 3 independent experiments $(\mathrm{n}=4$ per experiment). All compounds were dissolved in DMSO at stock concentration $100 \mathrm{~mm}$ (stored at $-20^{\circ} \mathrm{C}$ ) and diluted in culture medium immediately prior to use.

termined [20]. SNB19VR (hMSH6 loss) and U373VR (MGMT upregulation) revealed 7.9- and 4.3-fold greater resistance to TMZ ( $\mathrm{GI}_{50}$ values 280.2 and $288.8 \mu \mathrm{M}$, respectively) compared to parent cell lines SNB19V and $\mathrm{U} 373 \mathrm{~V}\left(\mathrm{GI}_{50}\right.$ values 35.7 and $68.0 \mu \mathrm{M}$, respectively; table 1, 2). In contrast, SNB19VR and U373VR cell lines were sensitive to the growth-inhibitory properties of analogs 10,11 and $13\left(\mathrm{GI}_{50}\right.$ values $\left.<65 \mu \mathrm{M}\right)$. Thus, novel imidazotetrazine analogs demonstrated no cross-resistance to TMZ in glioma cells.

\section{Cell Cycle Perturbations by Methyl Ester}

Imidazotetrazine in Glioma Cell Lines

To compare the effects of TMZ and methyl ester analog 11 on glioma cell cycle progression, DNA flow-cytometric analyses of SNB19V/M/VR cells following exposure to agents $(24-120 \mathrm{~h})$ were performed. After $48 \mathrm{~h}$ treatment with $100 \mu \mathrm{M}$ TMZ (clinically achieved concentration), $30.5 \%$ of the cells arrested at G2/M (compared with $17.5 \%$ of the control; fig. 1a). Further significant and prolonged accumulation of DNA in G2/M phases was observed after 72 and $120 \mathrm{~h}$ of exposure (37.1 and 47.7\%, respectively). Moreover, increased pre-G1 events (indicative of apoptotic cells) were observed after $\geq 72 \mathrm{~h}$ of exposure with $16.3 \%$ pre-G1 events after $120 \mathrm{~h}$ of treatment $(0.9 \%$ pre-G1 in the control). These data concur with previous reports that TMZ caused G2/M glioma cell cycle arrest $[16,31]$. In contrast, $100 \mu \mathrm{M}$ TMZ failed to perturb the SNB19M and SNB19VR cell cycles, a result attributed to competent MGMT activity (SNB19M) or deficient MMR (SNB19VR).

Upon exposure to analog $11(100 \mu \mathrm{M})$, increased $\mathrm{S}$ $(>12 \%)$ and G2/M (>11\%) SNB19V populations were detected during the first $24 \mathrm{~h}$; this small but persistent
G2/M accumulation was observed at $\leq 72 \mathrm{~h}$, and a small pre-G1 peak indicative of apoptosis induction emerged, increasing over time $(\leq 120 \mathrm{~h})$. In a manner comparable to SNB19V, SNB19M and SNB19VR cells also exhibited significant $S$ and G2/M arrest between 24 and 48 h exposure, with accompanying pre-G1 events $\geq 48$ h (fig. lb). At $200 \mu \mathrm{M}$, analog 11 caused more profound cell cycle arrest throughout the $S$ and $\mathrm{G} 2 / \mathrm{M}$ phases with higher percentage pre-G1 populations (not shown). These data indicate that $\mathrm{N}-3$ methyl ester imidazotetrazine 11 evokes perturbations in cell cycle progression earlier than TMZ in SNB19V cells, but distinct from TMZ, is able to perturb the SNB19M and SNB19VR cell cycles.

\section{UCN01-Increased TMZ and Methyl Ester \\ Imidazotetrazine 11 Cytotoxicity in Human \\ Glioma Cells}

Checkpoint 1 kinase (Chk1) plays a major role in regulation of the G2 cell cycle checkpoint. MTT assays were employed to assess the effects of UCN01, a Chk1 inhibitor [32] on TMZ and methyl ester 11 cytotoxicity. UCN01 alone (20 nM) had no deleterious effect on SNB19V cell viability and proliferation (fig. 1c, d), but was able to potentiate activities of both TMZ and analog 11. TMZ GI ${ }_{50}$ values reduced 3.5-fold, from 22.5 to $6.4 \mu \mathrm{M}$ and $\mathrm{GI}_{50}$ values of analog 11 reduced from 56.7 to $22.1 \mu \mathrm{M}$ (2.6-fold) in the presence of UCN01.

\section{Activity of Methyl and Ethyl Ester Analogs in BER+ and BER-Cell Lines}

Repair of N-7 guanine and N-3 adenine methylation damage is addressed primarily by BER [33]. It was hypothesized that methyl/ethyl ester analogs (11 and 13) 

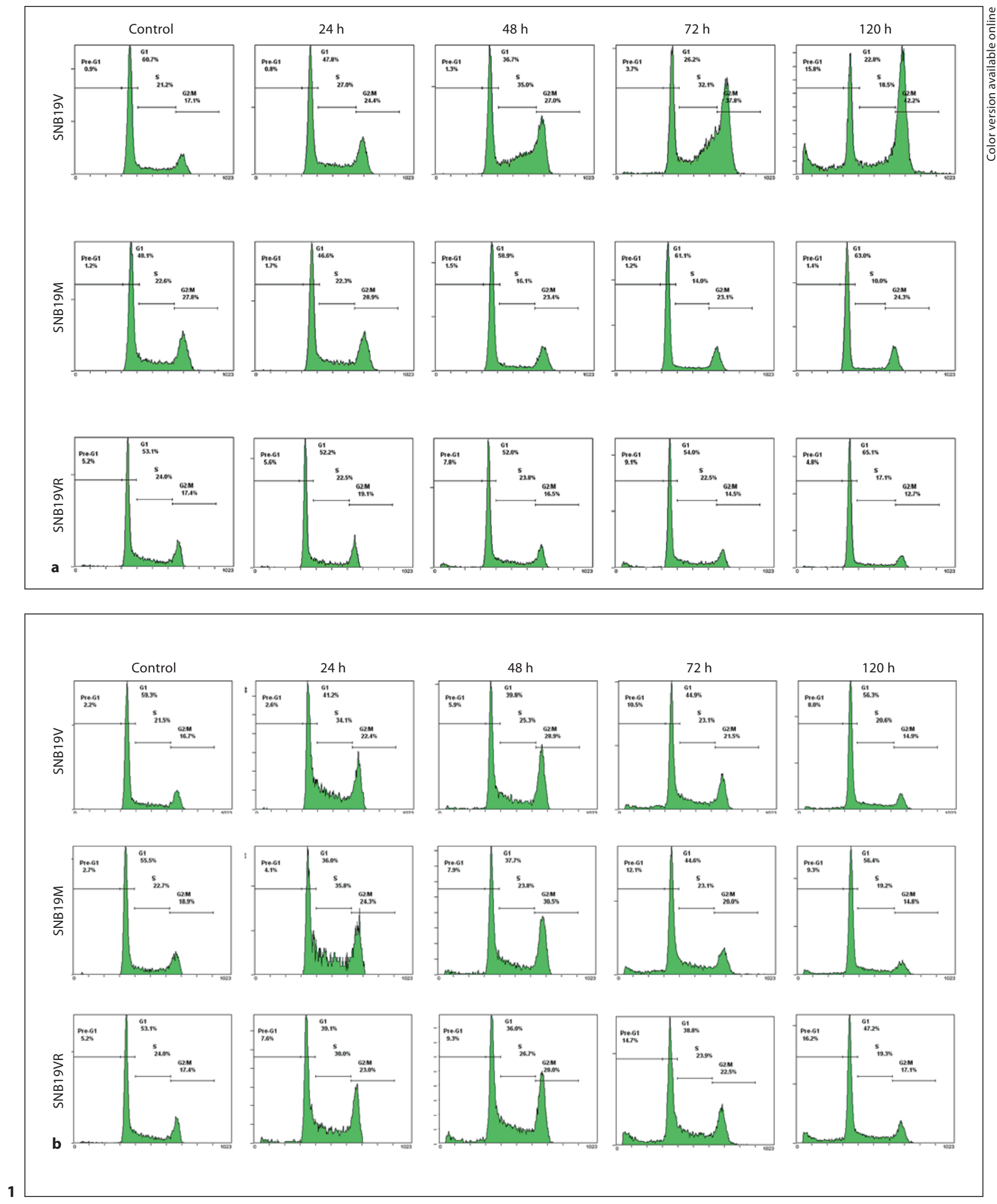

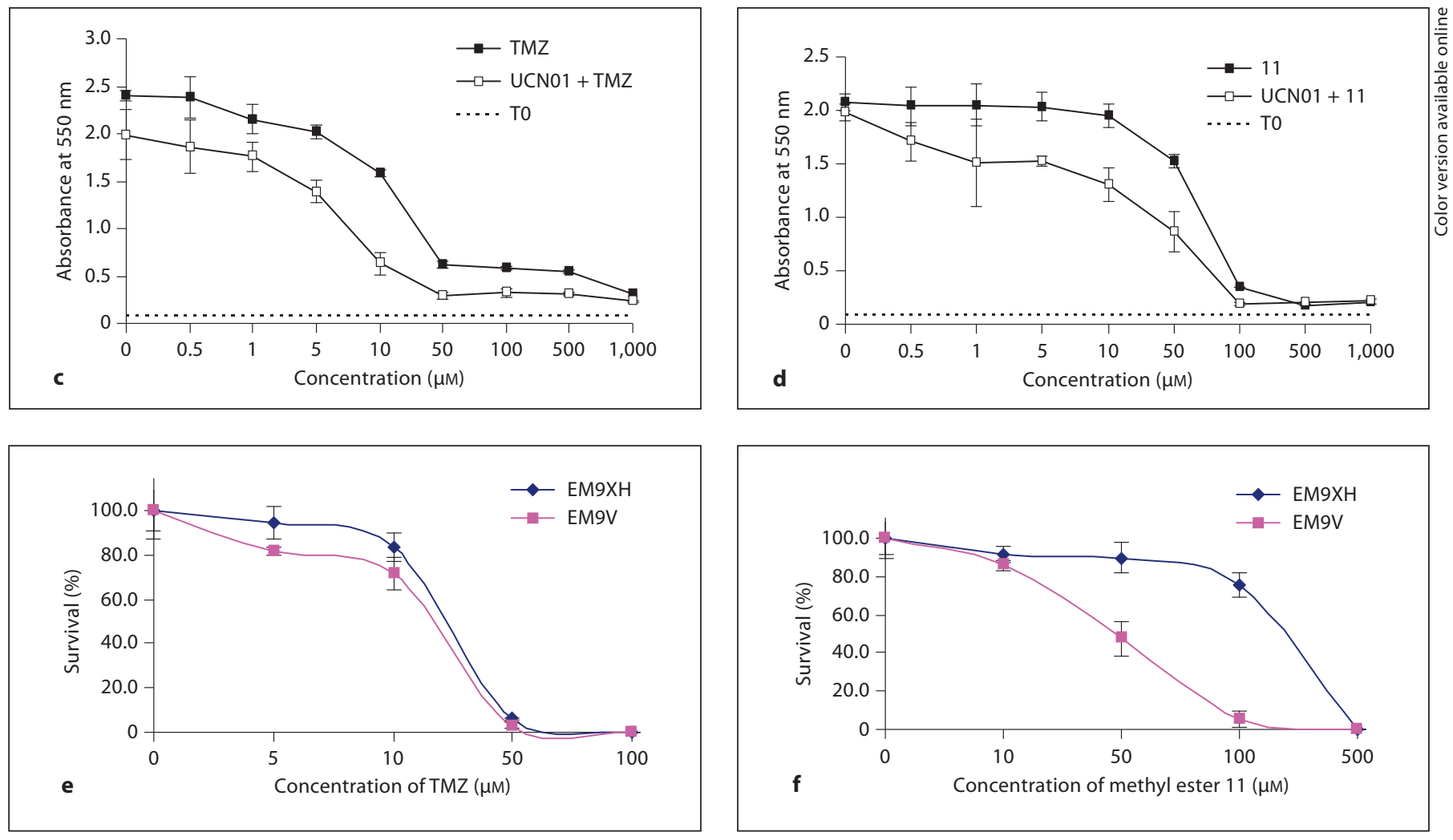

Fig. 1. Representative DNA histograms of SNB19 GBM cells following treatment with TMZ (a) or methyl ester analog 11 (100 $\mu \mathrm{M})$ (b). 10,000 events were evaluated; experiments were performed $\geq 3 \times$; $\mathrm{SD}<3 \%$. c, d Representative graphs illustrating the effect of UCN01 (20 nM) on TMZ- and analog 11-induced growth inhibition in SNB19V cells $(n=4$; experiments were repeated $3 \times$ ). e-g Sensitivity of EM9V and EM9XH cells to TMZ and analogs 11 and 13. Cells (150/well) were exposed to a series of concentrations of TMZ, methyl or ethyl ester analog (in triplicate). Following 11 days exposure, colonies were counted. Data represent mean $\pm \mathrm{SD}$ of at least 3 independent experiments.

modify bases at nucleophilic centers within DNA, such as N-7 guanine and N-3 adenine. To investigate BER involvement, clonogenic assays were performed in isogenic BER-proficient and BER-deficient $\mathrm{CHO}$ cell lines. BER- EM9V CHO cells are X-ray cross-complementing 1 (XRCC1) deficient and contain expression vector pc2DE; EM9XH, their isogenic BER-proficient partner cell line, expresses pcD2EXH which encodes C-terminally histidine-tagged XRCC1. EM9V cells are hypersensitive to ethyl and methyl methanesulfonate compared with EM9XH cells ( $\sim 10$-fold $[27,28])$. Enhanced sensitivity $<2$-fold was observed in EM9V cells compared to

EM9XH cells following TMZ treatment (fig. 1e-g). More strikingly, compared to the BER-proficient partner, BERdeficient EM9V cells demonstrated 3.75- and 5.07-fold enhanced sensitivity to imidazotetrazines 11 and 13, respectively, with $\mathrm{IC}_{50}$ values of 56.7 and $51.7 \mu \mathrm{M}$. More resistant EM9XH cells delivered $\mathrm{IC}_{50}$ values of 212.4 and $262.2 \mu \mathrm{M}$, following compound 11 and 13 challenge.

\section{Activity of Imidazotetrazine 11 in Combination with PARP Inhibition}

PARP-1 is a DNA damage sensor and signaling molecule activated by DNA strand breaks. PARP-1-catalyzed 
Table 3. Chemosensitivity of glioma and colon cells to TMZ and analog 11 alone and in the presence of PARP inhibitor NU1025

\begin{tabular}{lccllll}
\hline Cell line & \multicolumn{7}{l}{$\mathrm{GI}_{50}, \mu \mathrm{M}^{\mathrm{a}}$} & & & & \\
\cline { 2 - 6 } & $\mathrm{TMZ}$ & TMZ + NU1025 & fold & analog 11 & $\begin{array}{l}\text { analog } 11+ \\
\text { NU1025 }\end{array}$ & fold \\
\hline SNB19V & $33.2 \pm 19.3$ & $13.2 \pm 7.2$ & 2.5 & $53.5 \pm 13.9$ & $44.6 \pm 11.3$ & 1.2 \\
SNB19VR & $284.5 \pm 36.4$ & $105.8 \pm 38.2$ & 2.7 & $51.5 \pm 10.3$ & $37.9 \pm 13.2$ & 1.4 \\
U373V & $48.9 \pm 9.3$ & $12.8 \pm 1.6$ & 3.8 & $54.8 \pm 15.5$ & $29.5 \pm 2.4$ & 1.9 \\
U373VR & $307.5 \pm 99.8$ & $176.1 \pm 99.3$ & 1.7 & $59.9 \pm 8.1$ & $35.7 \pm 13.1$ & 1.7 \\
HCT116 & $358.4 \pm 12.0$ & $200.4 \pm 33.9$ & 1.8 & $31.9 \pm 2.1$ & $10.7 \pm 3.7$ & 3.0 \\
\hline
\end{tabular}

${ }^{\text {a }} \mathrm{GI}_{50}$ values were determined by 7-day MTT assay, data represent mean \pm SD of at least 3 independent experiments. ${ }^{\mathrm{b}} 100 \mu \mathrm{M}$ NU1025. ${ }^{\mathrm{c}}$ fold $=\mathrm{GI}_{50}$ values of compound alone/GI 50 values of compounds $+100 \mu \mathrm{M}$ NU1025.

poly(ADP-ribose) polymers attract recruitment of BER complex proteins, XRCC1, DNA polymerase $\beta$ and ligase III, to facilitate repair. PARP-1 activity has been implicated in the repair of N-methyl-purine adducts; inhibition of PARP-1 enhances TMZ cytotoxicity, particularly evident in MMR-defective cells where response to TMZ is poor compared to MMR-competent models [34, 35]. Potentiation of TMZ cytoxicity has been reported in vitro and in vivo with novel PARP inhibitors [36-38]. To investigate the effect of PARP-1 inhibition on the activity of novel TMZ analogs, combination assays were performed with NU1025 (100 $\mu \mathrm{M}$; table 3). NU1025 did not affect cell viability per se (data not shown), but enhanced TMZ cytotoxicity between 1.7- and 3.8-fold in glioma and CRC cells, attenuating resistance mediated by MGMT and MMR deficiency [20]. NU1025 increased cytotoxicity of analog 11 minimally in $-\mathrm{V}$ and -VR SNB19 populations, and by 1.9-, 1.7- and 3.0-fold in U373V, U373VR and HCT-116 cells, respectively.

\section{Novel TMZ Analogs Induce SSB and DSB in Glioma}

Cells and Initiate DNA Excision Repair

$\mathrm{N}$-alkylation induced by anticancer drugs accounts for the majority of alkylation products, primarily removed by BER and nucleotide excision repair (NER) [33]. The capacity of SNB19V cells to repair N-alkylation lesions following TMZ and imidazotetrazine 11 challenge $(100 \mu \mathrm{M} ; 2 \mathrm{~h})$ was compared. Following treatment, cells were washed (PBS) and incubated thereafter in fresh medium for up to $5 \mathrm{~h}$. Samples were analyzed by alkaline comet assay ( $\mathrm{pH}>13.0$ ); DNA migration is indicative of the amount of DNA SSBs and alkali-labile lesions within each cell. Tail moment, a measure of both the amount and distribution of DNA in the tail, was used to quantify DNA damage. Maximum increase in tail moment following TMZ treatment occurred $0.5 \mathrm{~h}$ after drug removal (fig. 2a); thereafter, tail moment values steadily decreased $(0.5-3 \mathrm{~h})$ indicating that subsequent time-dependent repair enabled the rejoining of incised DNA. In contrast, following exposure to analog 11 , tail moment values were maintained between 0.5 and $2 \mathrm{~h}$ after agent removal, subsequently decreasing minimally.

To confirm that comets were a consequence of the response of cells to imidazotetrazine 11, SNB19V cells were incubated with $20-500 \mu \mathrm{M}$ analog 11 for $2 \mathrm{~h}$ and analyzed immediately. Tail moment values increased concentration dependently (fig. 2b), suggesting that enhanced incision corresponds to increasing agent-induced DNA damage. Similar dose-dependent increases in tail moment were observed following treatment of SNB19V cells with TMZ (data not shown).

DNA damage effecting DSB formation induces rapid phosphorylation of Ser 139 at the carboxy terminus of histone $\mathrm{H} 2 \mathrm{AX}(\gamma \mathrm{H} 2 \mathrm{AX})$; such histone phosphorylation is a gold standard marker of DNA DSBs [39]. DSB formation was assessed in SNB19V cells following treatment with analog 11 and TMZ. Cells were treated with $100 \mu \mathrm{M}$ agent (2-72 h), lysates were prepared and Western blot was performed to allow detection of $\gamma \mathrm{H} 2 \mathrm{AX}$. Compound 11 induced H2AX phosphorylation within 2 $\mathrm{h}$, and levels persisted up to $72 \mathrm{~h}$. A slightly different time course for DSB appearance was observed following the treatment of cells with TMZ; although $\gamma \mathrm{H} 2 \mathrm{AX}$ could be detected following $2 \mathrm{~h}$ of treatment, levels continued to rise throughout the 72-hour experimental period (fig. 2c). 

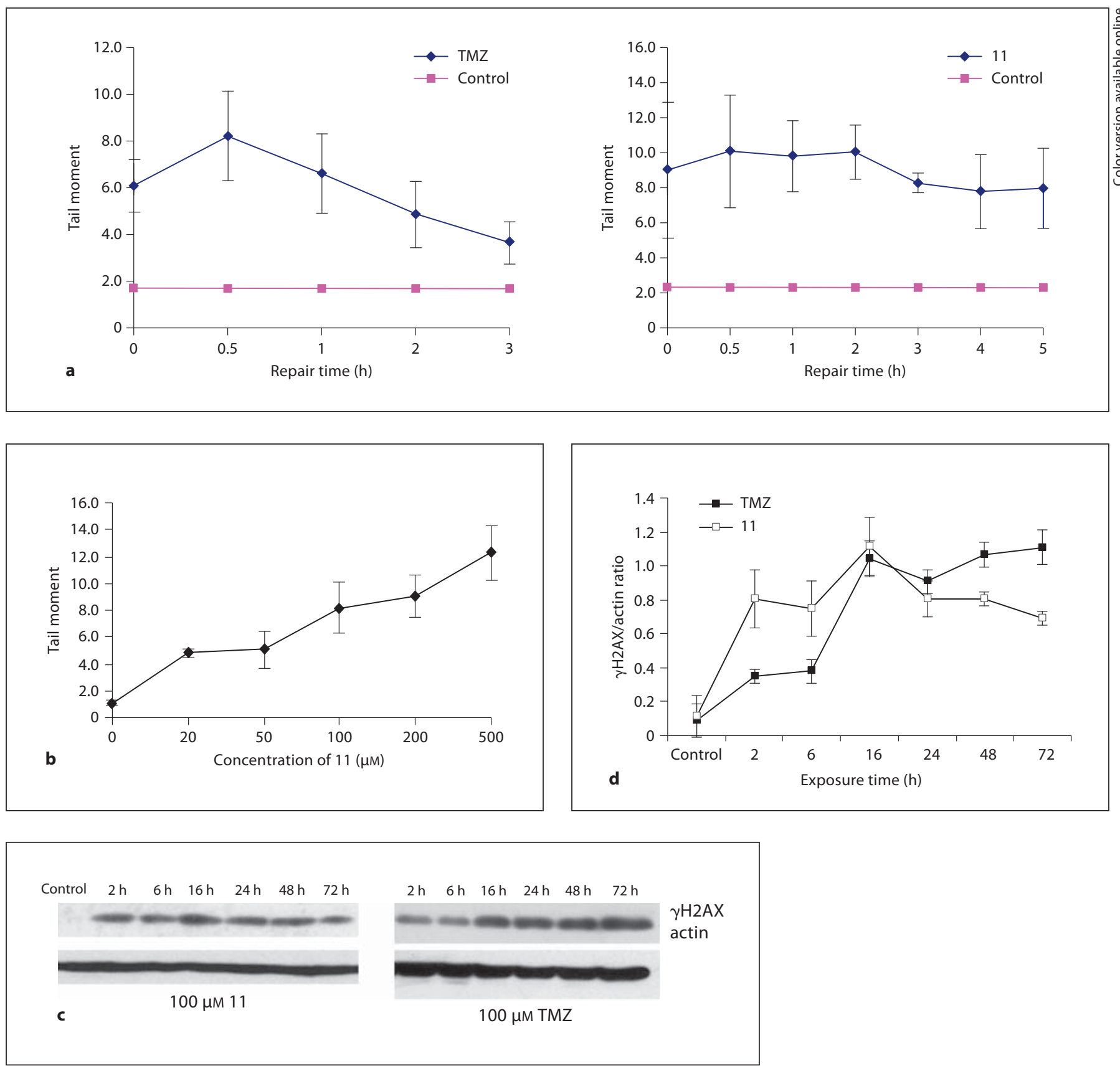

Fig. 2. a Time course of DNA excision repair in SNB19V cells following damage by TMZ and methyl ester analog 11. SNB19V cells were treated with $50 \mu \mathrm{M}$ TMZ and $100 \mu \mathrm{M}$ analog 11 for $2 \mathrm{~h}$, followed by incubation in fresh media. Samples were taken at indicated time points and analyzed by alkaline comet assay. Untreated cells were set as a control. Values are mean \pm SD of triplicate experiments. Strand-break formation by DNA excision repair in SNB19V cells initiated by TMZ and analog 11 was measured as tail moment. The tail moment value of untreated cells was set as a control. b Effect of increasing concentrations of analog 11 on DNA damage induced in SNB19V cells. SNB19V cells were treated with different concentrations of analog 11 for $2 \mathrm{~h}$. Samples were collected immediately after exposure and analyzed by alkaline comet assay. Values are mean $\pm \mathrm{SD}$ of triplicate experiments. c Induction of $\mathrm{H} 2 \mathrm{AX}$ phosphorylation in SNB19V cells following exposure to analog $11(100 \mu \mathrm{M})$ or TMZ $(100 \mu \mathrm{M})$. d $\gamma \mathrm{H} 2 \mathrm{AX}$ protein quantification was evaluated by densitometry (mean \pm $\mathrm{SD}, \mathrm{n}=3)$. 


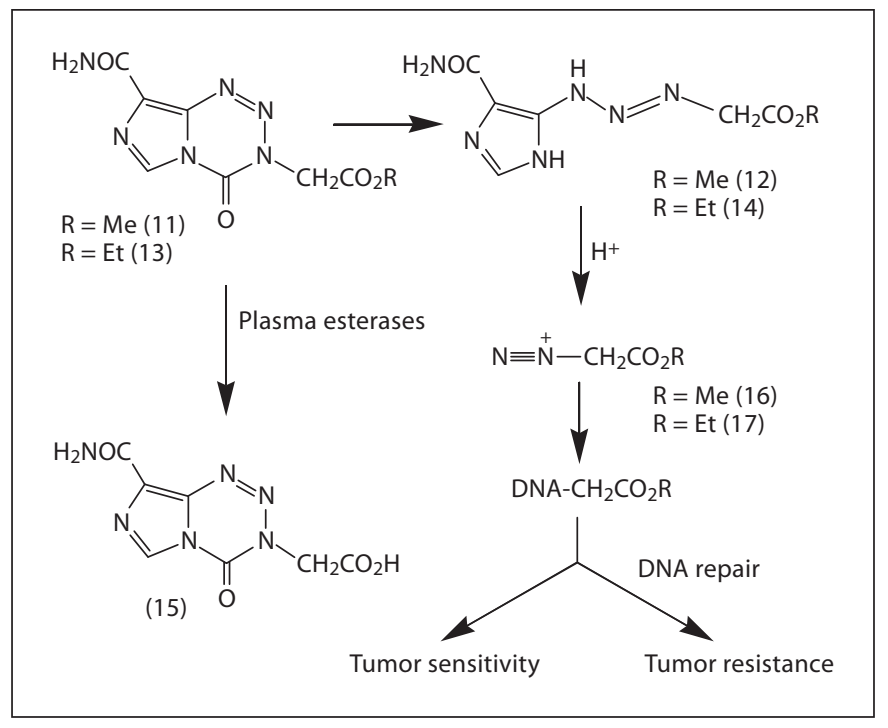

Fig. 3. Proposed activation/deactivation of ester analogs 11 and 13.

\section{Discussion}

The prognosis for patients diagnosed with malignant glioma is poor despite surgery, radiotherapy and alkylating-agent TMZ chemotherapy. The highest TMZ therapeutic efficacy is observed in tumors with low MGMT and intact MMR [11], with significantly greater responses to TMZ treatment in GBM patients whose MGMT gene promoter is methylated [4].

However, alkylating-agent treatment and radiotherapy may induce $M G M T$ gene expression [20, 40]. In addition, TMZ treatment has been shown to inactivate MMR, a result of mutation or loss of expression of the MMRassociated protein hMSH6 [20, 21, 41]. De novo or acquisition of drug resistance is a grave problem. Therefore, development of novel agents, with at least an equivalent potency to TMZ and the ability to overcome DNA repair associated with TMZ-induced O6-MeG, may not only offer a treatment option for GMB patients whose tumors express MGMT but also possess broader spectrum activity.

The growth-inhibitory activity of novel compounds was determined in isogenic GBM cell lines differing in their capacity to repair O6-alkylguanine lesions. TMZ analogs revealed potency equivalent to $\mathrm{TMZ}$ in vector control cells expressing negligible MGMT; moreover, MGMT-transfected cells were sensitive to growth-inhibitory properties. MMR-deficient CRC cell lines intrinsi- cally resistant to TMZ were sensitive to analogs 10,11 and 13. Furthermore, SNB19VR cells, which were MMR-deficient following the loss of hMSH6 protein and U373VR cells possessing upregulated MGMT, demonstrating acquired resistance to TMZ, retained sensitivity to compounds 10, 11 and 13 (table 2). Therefore, in vitro novel imidazotetrazine analogs irrefutably evaded MGMT and MMR.

Upon treatment with $100 \mu \mathrm{M}$ TMZ, MMR-proficient SNB19V cells arrested in S-G2/M cell cycle phases at $48 \mathrm{~h}$; after $72 \mathrm{~h}$, profound G2/M arrest was consistently observed, from which cells proceeded to apoptosis $(\geq 120 \mathrm{~h})$. Considerable evidence demonstrates that TMZ-induced G2/M arrest occurs at the second cycle after treatment and this response requires low/negligible MGMT levels and functional MMR [16]. Indeed, MGMTtransfected SNB19M and MMR-deficient SNB19VR cells continued cycling, failing to arrest or undergo apoptosis upon exposure to TMZ. Methyl ester analog $11(100 \mu \mathrm{M})$ caused more immediate S-G2/M arrest at 24 and $48 \mathrm{~h}$ in SNB19V/M and VR cells. Pre-G1 events were evident, particularly in SNB19VR populations $\geq 48 \mathrm{~h}$. These data suggest that putative O6-lesions delivered by analog 11 are not repaired by MGMT; if mispairs result, they are neither recognized nor repaired by MMR. Cycling cells stalled more immediately in the first cycle following treatment, as analog 11-derived adducts or DNA damage/ nicks caused by methyl-ester-derived adducts may alert $S$ phase checkpoints, arresting the cell cycle in S and G2/M as repair is attempted.

7-Hydroxystaurosporine (UCN01), an inhibitor of Chk1, is able to abrogate $\mathrm{S}$ and G2/M arrest triggered by DNA damage, preventing repair and advancing cell death due to the accumulation of excessive DNA damage [42]. In human glioblastoma cells, UCN01 has been reported to potentiate TMZ cytoxicity 5 -fold by enhancing the percentage of cells bypassing G2/M arrest.

Herein we describe the potentiation of both TMZ and methyl ester 11 cytotoxicity (3.5- and 2.6-fold, respectively) by UCN01. The greater potentiation of TMZ activity (compared to analog 11) corresponds to the more profound G2/M block following treatment of SNB19V cells with TMZ. Cell cycle analyses demonstrated that UCN01 (20 nM) was able to abrogate G2/M arrest associated with TMZ and methyl ester 11 treatment (at $\leq 72 \mathrm{~h}$ ), increasing the percentage of apoptotic cells (not shown). Collectively, the data infer that TMZ and analog 11 alert shared cell cycle checkpoints; thus a combination treatment with cell cycle checkpoint inhibitors could be applied to TMZ analogs. 
Similar to TMZ, novel analogs may cause base modification at nucleophilic centers within DNA such as N-7 guanine and N-3 adenine, lesions primarily addressed by BER. Therefore, BER-proficient and BER-deficient cell lines EM9XH and EM9V [27, 28], respectively, were used to investigate the potential contribution of BER. XRCC1 protein is devoid of known enzymatic activity, but functions as a scaffold protein in BER/SSBR processes, facilitating interactions between proteins of these related repair pathways [43]. XRCC1-deficient (BER-) cells demonstrate hypersensitivity to DNAdamaging agents [44]. EM9V cells show $\sim 10$-fold greater sensitivity to both ethyl and methyl methanesulfonate than EM9XH cells do, while having weak ( $<2$-fold) or no sensitivity to ionizing radiation $[43,44]$. As TMZ causes damage repaired by BER, and TMZ cytotoxicity is enhanced following BER disruption, it could be considered unexpected that this isogenic cell line pair failed to display disparity in sensitivity to TMZ. Recent literature also reports that EM9 cells reveal only a 2-fold greater sensitivity to TMZ [45]. However, XRCC1-deficient mouse fibroblasts (XRCC1 ${ }^{-/}$) are significantly hypersensitive to TMZ (15-fold). Western blot determined that EM9 cells do not express MGMT (result not shown); therefore, we argue that the primary toxic O6-MeG lesion induced by TMZ is responsible for cytotoxicity in EM9V and EM9XH cells. Interestingly, EM9XH cells are 3.75- and 5.07-fold more resistant to analogs 11 and 13, compared to EM9V cells. Such selective growth-inhibitory data infer that certain lesions induced by new analogs are subject to BER.

Disruption of BER through PARP inhibition potentiates TMZ cytotoxicity. In a manner similar to TMZ, ana$\log 11$ in combination with NU1025 showed enhanced anticancer activity against glioma and colon cells (table 3). These results corroborate data observed in EM9V and EM9XH cells, supporting the hypothesis that methyl ester analog 11 lesions activate BER.

Comet assays which measure DNA strand breaks in individual cells are widely used to detect DNA damage and repair kinetics $[46,47]$. The excision repair process initiated by genotoxic agents involves incision, excision of damaged nucleotides, subsequent gap filling by DNA resynthesis and strand religation. SSBs detected may be the result of direct strand breaks induced by TMZ and novel analogs, alkali-labile sites, or incision reactions by repair enzymes at DNA damage sites. $\mathrm{N}$-alkylation by TMZ is rapidly and efficiently repaired by BER. Consistent with this assertion, tail moments peaked at $0.5 \mathrm{~h}$, then steadily decreased until the last collection point at $3 \mathrm{~h}$. Con- versely, repair kinetics of analog 11-induced damage indicated the onset of repair only after $2 \mathrm{~h}$ after removal of the agent. This phenomenon may be explained by the fact that lesions induced by analog 11 are more 'bulky' than methyl purines.

Our observations indicated the following sequence of events upon exposure of SNB19V cells to TMZ: rapid generation of SSBs $(2 \mathrm{~h})$, with evidence of excision repair 30 min after TMZ removal, maximal generation of DSBs $\approx 72 \mathrm{~h}$, profound $\mathrm{G} 2 / \mathrm{M}$ cell cycle block $\geq 48 \mathrm{~h}$, preceding apoptosis as inferred by pre-G1 events $\geq 120 \mathrm{~h}$. These data support the large body of evidence demonstrating that $\mathrm{O} 6-\mathrm{MeG}$ induced by TMZ is converted during DNA replication into DSBs, assisted by futile cycles of MMR, which in turn triggers apoptosis in MGMT-low, MMRproficient cells only [48].

In contrast, dose-dependent DNA SSBs rapidly generated by methyl ester imidazotetrazine analog 11-induced lesions initiate reduced-capacity/slower-onset repair compared with SSB repair in cells exposed to TMZ. DNA damage alerts checkpoints which perturbs the cell cycle at $<24 \mathrm{~h}$ (S-G2/M arrest) irrespective of MGMT or MMR status. Putative N-3/N-7 purine adducts, subject to BER, cause DNA SSBs which appear more instantly to be converted to DSBs $(\gamma \mathrm{H} 2 \mathrm{AX}$ detected $2-72 \mathrm{~h}$ post treatment of SNB19V cells with $100 \mu \mathrm{M}$ analog 11); pre-G1 cell cycle events are indicative of apoptosis emerging after $48 \mathrm{~h}$ of exposure.

Such observations raise the hypothesis that lesions induced by novel N-3 methyl and ethyl ester imidazotetrazine analogs cause replication-independent formation of DSBs and apoptosis, in contrast to replication-dependent cell death caused by O6-MeG lesions delivered by TMZ.

Methyl (11) and ethyl (13) ester analogs are likely hydrolyzed by plasma esterases. Indeed, ex vivo addition of esters 11 and 13 to total-mouse plasma, followed by protein removal and quantification of remaining compound, revealed plasma instability, in contrast to TMZ which was readily recovered (unpublished). Carboxylic acid products of hydrolysis, exemplified by acetic acid analog (15), possess poor activity in the cell line panel (table 1). Design of analogs favoring ester conversion to free acid, predominantly in the liver, may circumvent plasma hydrolysis but would preclude oral administration, favoring other routes (i.v., i.m.) which would allow direct systemic drug absorption. Figure 3 summarizes proposed activation and deactivation of esters 11 and 13. Ring-opened imidazotetrazines 12 and 14 would (following the TMZ precedent) generate reactive diazonium species 16 and 17 
which would then alkylate DNA. The propensity for this lesion to be repaired critically mediates tumor sensitivity or resistance.

Although the pharmaceutical properties of imidazotetrazine analogs 11 and 13 preclude in vivo efficacy, we demonstrate novel N-3-methyl-substituted TMZ analogs are able to evade MGMT and MMR, heralding the possibility of treatment for GBM tumors whose MGMT promoter is not silenced, and wider-spectrum anticancer activity.

\section{Acknowledgements}

Financial support for all work described herein was provided by Pharminox Ltd. Dr. Jihong Zhang's PhD studentship stipend was funded by Pharminox Ltd.

\section{Disclosure Statement}

Dr. Tracey Bradshaw: paid consultant of Pharminox Ltd. Professor Malcolm Stevens: paid consultant of Pharminox Ltd, stockholder and recipient of stock options. Dr. Marc Hummersone: paid by Pharminox Ltd, stockholder and recipient of stock options.

\section{References}

1 Huse JT, Holland EC: Targeting brain cancer: advances in the molecular pathology of malignant glioma and medulloblastoma. Nat Rev Cancer 2010;10:319-331.

2 Laperriere N, Zuraw L, Cairncross G: Radiotherapy for newly diagnosed malignant glioma in adults: a systematic review. Radiother Oncol 2002;64:259-273.

-3 Stupp R, Hegi ME, Mason WP, van den Bent MJ, Taphoorn MJB, Janzer RC, Ludwin SK, Allgeier A, Fisher B, Belanger K, Hau P, Brandes AA, et al: Effects of radiotherapy with concomitant and adjuvant temozolomide versus radiotherapy alone on survival in glioblastoma in a randomised phase III study: 5-year analysis of the EORTC-NCIC trial. Lancet Oncol 2009;10:459-466.

4 Hegi ME, Liu L, Herman JG, Stupp R, Wick W, Weller M, Mehta MP, Gilbert MR: Correlation of O6-methylguanine methyltransferase (MGMT) promoter methylation with clinical outcomes in glioblastoma and clinical strategies to modulate MGMT activity. J Clin Oncol 2008;26:4189-4199.

$\checkmark 5$ Denny BJ, Wheelhouse RT, Stevens MF, Tsang LL, Slack JA: NMR and molecular modeling investigation of the mechanism of activation of the antitumor drug temozolomide and its interaction with DNA. Biochemistry 1994;33:9045-9051.

$\checkmark 6$ Tisdale MJ: Antitumor imidazotetrazines. $\mathrm{XV}$. Role of guanine O6 alkylation in the mechanism of cytotoxicity of imidazotetrazinones. Biochem Pharmacol 1987;36:457462 .

7 Wedge SR, Porteous JK, Newlands ES: 3-Aminobenzamide and/or O6-benzylguanine evaluated as an adjuvant to temozolomide or BCNU treatment in cell lines of variable mismatch repair status and O6-alkylguanine-DNA alkyltransferase activity. Br J Cancer 1996;74:1030-1036.

$\checkmark 8$ Margison GP, Santibanez-Koref MF: O-6alkylguanine-DNA alkyltransferase: role in carcinogenesis and chemotherapy. Bioessays $2002 ; 24: 255-266$.

\section{$>$}

9 D’Atri S, Tentori L, Lacal PM, Grazianin G, Pagani E, Benincasa E, Zambruno G, Bonmassar E, Jiricny J: Involvement of the mismatch repair system in temozolomide-induced apoptosis. Mol Pharmacol 1998;54: 334-341.

10 Pegg AE, Dolan ME, Moschel RC: Structure, function, and inhibition of O6-alkylguanine-DNA alkyltransferase. Prog Nucleic Acid Res Mol Biol 1995;51:167-223.

11 Gerson SL: Clinical relevance of MGMT in the treatment of cancer. J Clin Oncol 2002; 20:2388-2399.

12 Horton JK, Wilson SH: Hypersensitivity phenotypes associated with genetic and synthetic inhibitor-induced base excision repair deficiency. DNA Repair 2007;6:530-543.

13 Dantzer F, Schreiber V, Niedergang C, Trucco C, Flatter E, De La Rubia G, Oliver J, Rolli V, Ménissier-de Murcia J, de Murcia G: Involvement of poly(ADP-ribose) polymerase in base excision repair. Biochimie 1999;81: 69-75.

-14 Hirose Y, Berger MS, Pieper RO: P53 effects both the duration of $\mathrm{G}(2) / \mathrm{M}$ arrest and the fate of temozolomide-treated human glioblastoma cells. Cancer Res 2001;61:1957-1963.

- 15 Kanzawa T, Germano IM, Komata T, Ito H, Kondo Y, Kondo S: Role of autophagy in temozolomide-induced cytotoxicity for malignant glioma cells. Cell Death Differ 2004; 11:448-457.

-16 Roos WP, Batista LF, Naumann SC, Wick W, Weller M, Menck CFM, Kaina B: Apoptosis in malignant glioma cells triggered by the temozolomide-induced DNA lesion O6methylguanine. Oncogene 2007;26:186-197.

-17 Alvino E, Castiglia D, Caporali S, Pepponi R, Caporaso P, Lacal PM, Marra G, Fischer F, Zambruno G, Bonmassar E, Jiricny J, D’Atri $\mathrm{S}$ : A single cycle of treatment with temozolomide, alone or combined with O-6-benzylguanine, induces strong chemoresistance in melanoma cell clones in vitro: role of O-6methylguanine-DNA methyltransferase and the mismatch repair system. Int J Oncol 2006;29:785-797.
18 Esteller M, Herman JG: Generating mutations but providing chemosensitivity: the role of O6-methylguanine DNA methyltransferase in human cancer. Oncogene 2004;23:1-8.

-19 Stella A, Wagner A, Shito K, Lipkin SM, Watson P, Guanti G, Lynch HT, Fodde R, Liu B: A nonsense mutation in MLH1 causes exon skipping in three unrelated HNPCC families. Cancer Res 2001;61:7020-7024.

20 Zhang J, Stevens MF, Laughton CA, Madhusudan S, Bradshaw TD: Acquired resistance to temozolomide in glioma cell lines: molecular mechanisms and potential translational applications. Oncology 2010;78:103-114.

-21 Cahill DP, Levine KK, Betensky RA, Codd PJ, Romany CA, Reavie LB, Batchelor TT, Futreal PA, Stratton MR, Curry WT, Lafrate AJ, Louis DN: Loss of the mismatch repair protein MSH6 in human glioblastomas is associated with tumor progression during temozolomide treatment. Clin Cancer Res 2007; 13:2038-2045.

-22 Hunter C, Smith R, Cahill DP, Stephens P, Stevens C, Teague J, Greenman C, Edkins S, Bignell G, Davies H, O'Meara S, Parker A, et al: A hypermutation phenotype and somatic MSH6 mutations in recurrent human malignant gliomas after alkylator chemotherapy. Cancer Res 2006;66:3987-3991.

23 Wiewrodt D, Nagel G, Dreimuller N, Hundsberger T, Perneczky A, Kaina B: MGMT in primary and recurrent human glioblastomas after radiation and chemotherapy and comparison with p53 status and clinical outcome. Int J Cancer 2008;122:1391-1399.

24 Stevens MFG: Temozolomide: from cytotoxic to molecularly targeted agent; in Neidle S (ed): Cancer Drug Design and Discovery. Burlington, Academic Press, 2008, pp157162.

25 Stevens MFG, Cousin D, Jennings S, McCarroll AJ, Williams JG, Hummersone MG, Zhang J: 3-Substituted-4-oxo-3,4-dihydroimidazo-[5,1-D] $\quad[1,2,3,5]$-tetrazine-8-carboxylic acid amides as anticancer agents. WIPO Patent Application WO/2009/077741. 
26 Zhang J, Stevens MFG, Kerschmeier P, Hummersone $\mathrm{M}$, Laughton CA, Bradshaw TD: Novel temozolomide analogs may overcome MGMT and MMR. Mol Can Ther 2009; 8:A143.

27 Caldecott KW, Tucker JD, Thompson LH: Construction of human XRCC1 minigenes that fully correct the CHO DNA repair mutant EM9. Nucleic Acids Res 1992;20:45754579.

-28 Caldecott KW, Tucker JD, Stanker LH, Thompson LH: Characterization of the XRCC1-DNA ligase III complex in vitro and its absence from mutant hamster cells. Nucleic Acids Res 1995;23:4836-4843.

-29 Nicoletti I, Migliorati G, Pagliacci MC, Grignani F, Riccardi C: A rapid and simple method for measuring thymocyte apoptosis by propidium iodide staining and flow cytometry. J Immunol Methods 1991;139:271-279.

- 30 Brown GD, Luthra SK, Brock CS, Stevens MFG, Price PM, Brady F: Antitumor imidazotetrazines. 40. Radiosyntheses of [4-C11-carbonyl]- and [3-N-C-11-methyl]-8-carbamoyl-3-methylimidazo[5,1-d]-1,2,3,5tetrazin-4(3H)-one (temozolomide) for positron emission tomography (PET) studies. J Med Chem 2002;45:5448-5457.

- 31 Hirose Y, Berger MS, Pieper RO: Abrogation of the Chk1-mediated G(2) checkpoint pathway potentiates temozolomide-induced toxicity in a p53-independent manner in human glioblastoma cells. Cancer Res 2001;61: 5843-5849.

-32 Prudhomme M: Novel checkpoint 1 inhibitors. Recent Pat Anticancer Drug Discov 2006; 1:55-68.

- 33 Plosky B, Samson L, Engelward BP, Gold B, Schlaen B, Millas T, Magnotti M, Schor J, Scicchitano DA: Base excision repair and nucleotide excision repair contribute to the removal of $\mathrm{N}$-methylpurines from active genes. DNA Repair 2002;1:683-696.
34 Curtin NJ, Wang LZ, Yiakouvaki A, Kyle S, Arnis CA, Canon-Kock S, Webber SE, Durkacz BW, Calvert HA, Hostomsky Z, Newell DR: Novel poly(ADP-ribose) polymerase-1 inhibitor, AG14361, restores sensitivity to temozolomide in mismatch repair-deficient cells. Clin Cancer Res 2004;10:881-889.

35 Tentori L, Leonetti C, Scarsella M, D’Amati G, Portarena I, Zupi G, Bonmassar E, Graziana G: Combined treatment with temozolomide and poly(ADP-ribose) polymerase inhibitor enhances survival of mice bearing hematologic malignancy at the central nervous system site. Blood 2002;99: 2241-2244.

36 Calabrese CR, Almassy R, Barton S, Batey MA, Calvert HA, Canan-Koch S, Durkacz BW, Hostomsky Z, Kumpf RA, Kyle S, Li J, Maegley K, et al: Anticancer chemosensitization and radiosensitization by the novel poly(ADP-ribose) polymerase-1 inhibitor AG14361. J Natl Cancer Inst 2004;96:5667.

37 Cheng CL, Johnson SP, Keir ST, Quinn JA, Ali-Osman F, Szabo C, Li H, Salzman AL, Dolan ME, Medrich P, Bigner DD, Friedman HS: Poly(ADP-ribose) polymerase-1 inhibition reverses temozolomide resistance in a DNA mismatch repair-deficient malignant glioma xenograft. Mol Cancer Ther 2005;4: 1364-1368.

38 Tentori L, Leonetti C, Scarsella M, D’Amat G, Vergati M, Portarena I, Xu W, Kalish V, Zupi G, Zhang J, Graziani G: Systemic administration of GPI 15427, a novel poly(ADPribose) polymerase-1 inhibitor, increases the antitumor activity of temozolomide against intracranial melanoma, glioma, lymphoma. Clin Cancer Res 2003;9:5370-5379.
-39 Rogakou EP, Pilch DR, Orr AH, Ivanova VS, Bonner WM: DNA double-stranded breaks induce histone $\mathrm{H} 2 \mathrm{AX}$ phosphorylation on serine 139. J Biol Chem 1998;273:5858-5868.

40 Grombacher T, Mitra S, Kaina B: Induction of the alkyltransferase (MGMT) gene by DNA damaging agents and the glucocorticoid dexamethasone and comparison with the response of base excision repair genes. Carcinogenesis 1996;17:2329-2336.

41 Yip S, Miao J, Cahill DP, Iafrate AJ, Aldape K, Nutt CL, Louis DN: MSH6 mutations arise in glioblastomas during temozolomide therapy and mediate temozolomide resistance. Clin Cancer Res 2009;15:4622-4629.

42 Wang Q, Fan S, Eastman A, Worland PJ, Sausville EA, O'Connor PM: UCN-01: a potent abrogator of $\mathrm{G} 2$ checkpoint function in cancer cells with disrupted p53. J Natl Cancer Inst 1996;88:956-965.

43 Caldecott KW: XRCC1 and DNA strand break repair. DNA Repair 2003;2:955-969.

-44 Thompson LH, West MG: XRCC1 keeps DNA from getting stranded. Mutat Res 2000;459:1-18.

45 Horton JK, Watson M, Stefanick DF, Shaughnessy DT, Taylor JA, Wilson SH: XRCC1 and DNA polymerase beta in cellular protection against cytotoxic DNA single-strand breaks. Cell Res 2008; 18:48-63.

46 Collins AR: The comet assay for DNA damage and repair: principles, applications, and limitations. Mol Biotechnol 2004;26:249261.

47 Fortini P, Raspaglio G, Falchi M, Dogliotti E: Analysis of DNA alkylation damage and repair in mammalian cells by the comet assay. Mutagenesis 1996;11:169-175.

48 Roos W, Baumgartner M, Kaina B: Apoptosis triggered by DNA damage O-6-methylguanine in human lymphocytes requires DNA replication and is mediated by $\mathrm{p} 53$ and Fas/ CD95/Apo-1. Oncogene 2004;23:359-367. 